\title{
Socio-demographic characteristics and quality of life of elderly patients with systemic arterial hypertension who live in rural areas: the importance of nurses' role ${ }^{1}$
}

\author{
Darlene Mara dos Santos Tavares ${ }^{2}$ \\ Mariana Mapelli de Paiva ${ }^{3}$ \\ Flavia Aparecida Dias ${ }^{4}$ \\ Marina Aleixo Diniz ${ }^{5}$ \\ Nayara Paula Fernandes Martins ${ }^{6}$
}

Objective: To describe the socio-demographic characteristics and quality of life of elderly patients with systemic arterial hypertension; to correlate the quality of life with the time of diagnosis and number of medication, as well as to compare the quality of life with the type of medication. Method: In this cross sectional home survey design, 460 elderly people from rural areas were involved. The data was collected with the use of the following instruments: World Health Organization Quality of Life-bref and World Health Organization Quality of Life Olders. A descriptive analysis, Pearson correlation and t-Student test $(p<0.05)$ were undertaken. Results: Predominant patient characteristics were: women between the age of 60 and 70, married, four to eight years of formal education, income of one minimum wage, living with their partners. The time of diagnosis was associated with lower quality of life in the physical domain. Elderly patients who used Inhibitors and Angiotensin Converting Enzyme and who did not use AT1 blocker had lower scores in relation to functioning of the senses. Those who used calcium channel blocker scored higher in relation to autonomy. Conclusion: there is a need for actions to control systemic arterial hypertension and its associated complications, with the purpose of improving quality of life.

Descriptors: Hypertension; Quality of Life; Health of the Elderly; Rural Population; Nursing.

\footnotetext{
${ }^{1}$ Supported by Conselho Nacional de Desenvolvimento Científico e Tecnológico (CNPq), process \# 503646/2009-1.

2 PhD, Associate Professor, Departamento de Enfermagem em Educação e Saúde Comunitária, Universidade Federal do Triângulo Mineiro, Uberaba, MG, Brazil.

3 Undergraduate student in Nursing, Universidade Federal do Triângulo Mineiro, Uberaba, MG, Brazil. Scholarship holder from Fundação de Amparo à Pesquisa do Estado de Minas Gerais (FAPEMIG), Brazil.

${ }^{4}$ MSc, Substitute Professor, Departamento de Enfermagem em Educação e Saúde Comunitária, Universidade Federal do Triângulo Mineiro, Uberaba, MG, Brazil.

5 Doctoral Student, Escola de Enfermagem de Ribeirão Preto, Universidade de São Paulo, WHO Collaborating Centre for Nursing Research Development, Ribeirão Preto, SP, Brazil.

${ }^{6}$ MSc, Scholarship holder - technical support, Fundação de Amparo à Pesquisa do Estado de Minas Gerais (FAPEMIG), Brazil.
}

Corresponding Author:

Darlene Mara dos Santos Tavares

Universidade Federal do Triângulo Mineiro

Pç. Manoel Terra, 330

Bairro: Abadia

CEP: 38100-000, Uberaba, MG, Brasil

E-mail: darlenetavares@enfermagem.uftm.edu.br 


\section{Introduction}

The process of human aging is a reality worldwide ${ }^{(1)}$. The increase in life expectancy is a result of a dynamic interaction between birth and death rates, associated with the technical scientific development and improvement of basic sanitation conditions ${ }^{(2)}$.

The change in the age composition of the population was followed by changes in morbimortality causes, with higher incidence of chronic diseases. Among these, systemic arterial hypertension ( $\mathrm{SAH}$ ) can be highlighted, a multifactor medical condition which can cause functional changes in target organs like the heart, the brain, the kidneys and the blood vessels(3). In Brazil, according to the Risk Factors Surveillance and protection for chronic diseases by way of telephone survey (VIGITEL), SAH affects approximately $60.2 \%$ of the population over 65 years of age ${ }^{(2)}$.

Several factors may contribute to the occurrence of the $\mathrm{SAH}$, some of which are considered unchangeable, such as genetic inheritance, age, gender and ethnics, and some considered changeable, such as salt intake, stress, sedentary lifestyle, alcohol intake, smoking, among other factors ${ }^{(4)}$. The changeable factors are subject to the healthcare professional's action aimed at preventing $\mathrm{SAH}$ and maintaining quality of life (QoL).

The concept of QoL is considered subjective, multidimensional, with positive and negative aspects. It was defined by a group of academics supported by the World Health Organization (WHO) as "individuals' perception of their position in life in the context of the culture and value systems in which they live and in relation to their goals, expectations, standards and concerns" (5). However, among those with $\mathrm{SAH}$, QoL has been related to therapy, changes in lifestyle, personal habits, as well as the organization of healthcare, which can contribute to relieve the symptoms ${ }^{(6)}$. A study involving adults and elderly with $\mathrm{SAH}$, using the instrument Short-Form-36 Health Survey (SF-36), showed that SAH affects QoL in the following aspects: general health status; physical, emotional and social performance; pain, vitality and mental health(7).

In addition, the QV of people with HAS may be affected by income, time of diagnosis, comorbidities and side effects of medications ${ }^{(4,8)}$.

In this context, it can be noted that studies carried out in rural areas are rare, especially those which evaluate the QoL of elderly with SAH. The aging process of the rural area population is similar to that in the urban area; however, there may be greater difficulties due to poverty, social isolation, poor education, more precarious housing, restricted access to transport and distance from social resources and healthcare institutions ${ }^{(1,9)}$.

The objectives were to describe the sociodemographic and economic characteristics and QoL of elderly people with $\mathrm{SAH}$ who live in the rural area of Uberaba city; to correlate the QoL scores with the time of diagnosis of the SAH and with the number of medications used; to compare the elderly people's QoL score with the type of medication used.

\section{Methods}

This study is part of a larger, population based, analytical, cross sectional and observational research which involved 850 elderly people living in the rural area of Uberaba, a city in the state of Minas Gerais.

The criteria for inclusion were: to be over 60 years of age, to live in the rural area of Uberaba-MG, to achieve the minimum score in the cognitive assessment, to auto diagnose with $\mathrm{SAH}$ and agree to participate in the research. There were 460 elderly people who matched the inclusion criteria.

The cognitive assessment was undertaken through the Mini Mental State Examination (MMSE), which was translated and validated in Brazil(10). The MMSE provides information about the different cognitive parameters, grouped into seven categories. The following cut-off points were established: 13 for illiterates, 18 for formal education from 1 to 11 years and 26 for formal education of more than 11 years ${ }^{(10)}$.

In order to describe the profile of the elderly, a structured instrument based on the questionnaire Older Americans Resources and Services (OARS), developed by Duke University, was used and adapted to the Brazilian scenario(11). The socio-economic and demographic characteristics studied were: gender, age group, marital status, educational level in years of study, living arrangements and individual monthly income in minimum wages.

The QoL was assessed through the World Health Organization Quality of Life-bref (WHOQOL-BREF), general and validated in Brazil(12). This consists of four factors: physical, psychological, social relationships and environment ${ }^{(12)}$. The instrument World Health Organization Quality of Life Olders (WHOQOL-OLD) is specific to the elderly situation and has also been validated in Brazil(13). It measures QoL using six aspects: sensorial functioning, autonomy, past, present and future activities, social participation, death and dying and intimacy ${ }^{(13)}$. 
Concerning the questions related to the $\mathrm{SAH}$, an instrument developed by the researchers was used, and involved the following: time of diagnosis (in years); how the disease was discovered; use and type of medication; reasons for discontinuing the medications; habit of measuring blood pressure and salt intake with the food. A pilot test was conducted to verify the suitability of the mentioned instrument to the proposed objectives.

The classification of the $6^{\text {th }}$ Brazilian Hypertension Guidelines was used to classify the medications for antihypertensive therapy: diuretics, adrenergic inhibitors, inhibitors of angiotensin-converting enzyme (IACE), calcium channel blockers, AT1 receptor blockers (BRA II) and direct vasodilator ${ }^{(3)}$.

Fourteen trained interviewers collected the data at the patients' homes between June 2010 and March 2011.

A spreadsheet was developed in the program Excel $^{\circledR}$, the data collected were processed into a microcomputer using double data entry. Later, in order to carry out the analysis, the data was transferred to the software Statistical Package for the Social Sciences (SPSS) version 17.0.

Data were analyzed through absolute frequencies, percentage, average and standard deviation. Student's $\mathrm{t}$ and Pearson's Correlation test $(p<0.05)$ were used. The correlation intensity was interpreted as very

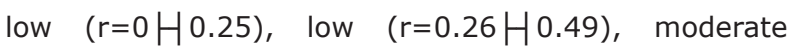
$(r=0.5 H 0.69)$, high $(r=0.7 H 0.89)$ and very high $(r=0.9 H 1.0)$. Each factor of WHOQOL-BREF and aspect of WHOQOL-OLD were analyzed separately, with their own syntaxes. The scores varied from zero to 100 , with the highest ones meaning better QoL.

The project received approval from the Ethics Committee on Human Research at Universidade Federal do Triângulo Mineiro under registration number 1477.
The interview was conducted after the interviewees' consent and signature of the mentioned form.

\section{Results}

Predominant patient characteristics were: women (53.9\%) between the age of 60 and $70(59.1 \%)$, married $(65.1 \%), 1$ to 4 years of formal education (32.3\%), income of one minimum wage $(49.6 \%)$, and who lived only with their partners (45.7\%).

The majority of the elderly reported having the diagnosis of HAS for more than ten years (52.9\%), which was found during a routine medical examination $(43.8 \%)$ and when they sought healthcare after feeling unwell $(41.6 \%)$. Most of them were used to measuring the blood pressure $(90.5 \%)$ and used medication (95.9\%) and, from these, $51.3 \%$ reported to undertake monotherapy.

It can be noted that $21.3 \%$ of the elderly stated to have discontinued the treatment before, $15.2 \%$ of them due to having forgotten to take it, $13.1 \%$ due to not showing any symptoms and $12 \%$ due to believing they were cured. Most of them affirmed to use little salt in their food $(90.5 \%)$.

Concerning QoL, the elderly evaluated it as good (57.1\%) and were satisfied with their health (59.9\%).

In relation to QoL and the time of the $\mathrm{SAH}$ diagnosis, it could be noted that the longer the time, the lower the QoL score in relation to the physical factor, the correlation being very low $(r=-0.11 ; p=0.019)$; there was no correlation with other factors and aspects.

There was no correlation between the number of medications used and the QoL.

Table 1 below shows the scores of the QoL in relation to the type of medication used.

Table 2 below shows the QoL scores (WHOQOL-OLD) in relation to the type of medication the participants used.

Table 1 - Distribution of QoL scores (WHOQOL-BREF) in relation to the type of medication used for the SAH treatment. Uberaba, MG, Brazil, 2011

\begin{tabular}{|c|c|c|c|c|}
\hline Medication & Physical & Psychological & Social relationships & Environment \\
\hline \multicolumn{5}{|l|}{ IACE } \\
\hline Yes & 66.48 & 69.04 & 73.34 & 61.53 \\
\hline \multirow[t]{3}{*}{ No } & 64.59 & 68.80 & 74.03 & 63.24 \\
\hline & $t=1.280$ & $t=0.202$ & $t=-0.579$ & $t=-1.558$ \\
\hline & $p=0.201$ & $p=0.840$ & $p=0.563$ & $p=0.120$ \\
\hline \multicolumn{5}{|c|}{ Calcium Channel Blocker } \\
\hline Yes & 62.75 & 68.60 & 76.49 & 62.28 \\
\hline \multirow[t]{3}{*}{ No } & 66.03 & 68.98 & 73.26 & 62.30 \\
\hline & $t=-1.460$ & $t=-0.205$ & $t=1.786$ & $t=-0.014$ \\
\hline & $p=0.145$ & $p=0.838$ & $p=0.075$ & $p=0.989$ \\
\hline
\end{tabular}


Table 1 - (continuation)

\begin{tabular}{|c|c|c|c|c|}
\hline Medication & Physical & Psychological & Social relationships & Environment \\
\hline \multicolumn{5}{|l|}{ Direct Vasodilator } \\
\hline Yes & 50 & 47.91 & 66.66 & 54.68 \\
\hline \multirow[t]{3}{*}{ No } & 65.70 & 69.02 & 73.68 & 62.33 \\
\hline & $t=-1.406$ & $t=-2.290$ & $t=-0.779$ & $t=-0.921$ \\
\hline & $p=0.160$ & $p=0.022$ & $p=0.436$ & $p=0.357$ \\
\hline \multicolumn{5}{|l|}{ Diuretics } \\
\hline Yes & 64.84 & 67.96 & 73.55 & 62.23 \\
\hline \multirow[t]{3}{*}{ No } & 66.39 & 69.85 & 73.74 & 62.35 \\
\hline & $t=-1.058$ & $t=-1.560$ & $t=-0.160$ & $t=-0.110$ \\
\hline & $p=0.291$ & $p=0.119$ & $p=0.873$ & $p=0.912$ \\
\hline \multicolumn{5}{|c|}{$\begin{array}{l}\text { Central Adrenergic Inhibitor + } \\
\text { Beta blocker }\end{array}$} \\
\hline Yes & 66.05 & 69.20 & 73.84 & 62.25 \\
\hline \multirow[t]{3}{*}{ No } & 63.33 & 67.49 & 72.65 & 62.59 \\
\hline & $t=-1.341$ & $t=1.015$ & $t=-0.721$ & $t=-0.227$ \\
\hline & $p=0.181$ & $p=0.311$ & $p=0.471$ & $p=0.821$ \\
\hline \multicolumn{5}{|l|}{ BRA II } \\
\hline Yes & 64.08 & 68.45 & 73.69 & 61.74 \\
\hline \multirow[t]{3}{*}{ No } & 65.92 & 69.03 & 73.64 & 62.40 \\
\hline & $t=-0.896$ & $t=-0.336$ & $t=0.027$ & $t=-0.432$ \\
\hline & $p=0.371$ & $p=0.737$ & $p=0.979$ & $p=0.666$ \\
\hline \multicolumn{5}{|l|}{ Adrenergic Inhibitor } \\
\hline Yes & 61.94 & 68.53 & 74.71 & 61.85 \\
\hline \multirow[t]{3}{*}{ No } & 65.88 & 68.96 & 73.58 & 62.33 \\
\hline & $t=-1.303$ & $t=-0.171$ & $t=0.464$ & $t=-0.211$ \\
\hline & $p=0.193$ & $p=0.864$ & $p=0.643$ & $p=0.833$ \\
\hline
\end{tabular}

Table 2 - Distribution of the QoL scores (WHOQOL-OLD) in relation to the type of medication used for SAH treatment. Uberaba, MG, Brazil, 2011

\begin{tabular}{|c|c|c|c|c|c|c|}
\hline Medication & $\begin{array}{c}\text { Functioning of } \\
\text { senses }\end{array}$ & Autonomy & $\begin{array}{l}\text { Past, present and } \\
\text { future activities }\end{array}$ & $\begin{array}{c}\text { Social } \\
\text { participation }\end{array}$ & Death and dying & Intimacy \\
\hline \multicolumn{7}{|l|}{ IACE } \\
\hline Yes & 68.40 & 67.27 & 69.24 & 66.02 & 70.20 & 72.59 \\
\hline \multirow[t]{3}{*}{ No } & 73.13 & 67.12 & 70.07 & 67.33 & 73.70 & 74.15 \\
\hline & $t=-2.208$ & $t=0.074$ & $t=-0.763$ & $t=-1.091$ & $t=-1.544$ & $t=-0.959$ \\
\hline & $p=0.028$ & $p=0.941$ & $p=0.446$ & $p=0.276$ & $p=0.123$ & $p=0.338$ \\
\hline \multicolumn{7}{|c|}{ Calcium Channel Blocker } \\
\hline Yes & 70.76 & 73.66 & 68.52 & 67.52 & 70.53 & 72.99 \\
\hline \multirow[t]{3}{*}{ No } & 70.48 & 66.31 & 69.76 & 66.48 & 71.93 & 73.33 \\
\hline & $t=0.085$ & $t=2.448$ & $t=-0.733$ & $t=0.569$ & $t=-0.405$ & $t=-0.139$ \\
\hline & $p=0.932$ & $p=0.015$ & $p=0.464$ & $p=0.569$ & $p=0.686$ & $p=0.889$ \\
\hline \multicolumn{7}{|l|}{ Direct Vasodilator } \\
\hline Yes & 40.62 & 37.50 & 71.87 & 59.37 & 21.87 & 87.50 \\
\hline \multirow[t]{3}{*}{ No } & 70.64 & 67.32 & 69.60 & 66.63 & 71.98 & 73.22 \\
\hline & $t=-1.848$ & $t=-1.994$ & $t=0.271$ & $t=-0.800$ & $t=-2.940$ & $t=1.182$ \\
\hline & $p=0.65$ & $p=0.47$ & $p=0.786$ & $p=0.424$ & $p=0.003$ & $p=0.238$ \\
\hline \multicolumn{7}{|l|}{ Diuretics } \\
\hline Yes & 70.61 & 66.47 & 69.63 & 66.97 & 71.47 & 74.19 \\
\hline \multirow[t]{3}{*}{ No } & 70.42 & 67.88 & 69.59 & 66.26 & 72.04 & 72.44 \\
\hline & $t=-1.210$ & $t=-0.498$ & $t=0.405$ & $t=-0.567$ & $t=-0.593$ & $t=-0.707$ \\
\hline & $p=0.227$ & $p=0.618$ & $p=0.685$ & $p=0.571$ & $p=0.554$ & $p=0.480$ \\
\hline
\end{tabular}


Table 2 - (continuation)

\begin{tabular}{|c|c|c|c|c|c|c|}
\hline Medication & $\begin{array}{l}\text { Functioning of } \\
\text { senses }\end{array}$ & Autonomy & $\begin{array}{l}\text { Past, present and } \\
\text { future activities }\end{array}$ & $\begin{array}{c}\text { Social } \\
\text { participation }\end{array}$ & Death and dying & Intimacy \\
\hline \multicolumn{7}{|c|}{$\begin{array}{l}\text { Central Adrenergic } \\
\text { Inhibitor + Beta blocker }\end{array}$} \\
\hline Yes & 70.96 & 66.94 & 69.72 & 66.85 & 72.48 & 73.63 \\
\hline \multirow[t]{3}{*}{ No } & 68.04 & 68.66 & 69.01 & 65.23 & 67.78 & 71.39 \\
\hline & $t=-0.984$ & $t=-0.631$ & $t=0.463$ & $t=0.987$ & $t=1.507$ & $t=1.020$ \\
\hline & $p=0.326$ & $p=0.528$ & $p=0.644$ & $p=0.324$ & $p=0.133$ & $p=0.308$ \\
\hline \multicolumn{7}{|l|}{ BRA II } \\
\hline Yes & 75.53 & 67.23 & 68.92 & 67.94 & 71.96 & 76.52 \\
\hline \multirow[t]{3}{*}{ No } & 69.62 & 67.19 & 69.73 & 66.37 & 71.73 & 72.72 \\
\hline & $t=1.990$ & $t=0.013$ & $t=-0.525$ & $t=0.949$ & $t=0.074$ & $t=1.723$ \\
\hline & $p=0.047$ & $p=0.462$ & $p=0.600$ & $p=0.343$ & $p=0.941$ & $p=0.086$ \\
\hline \multicolumn{7}{|l|}{ Adrenergic Inhibitor } \\
\hline Yes & 65.52 & 65.30 & 68.75 & 65.30 & 69.18 & 71.12 \\
\hline \multirow[t]{3}{*}{ No } & 70.85 & 67.33 & 69.67 & 66.69 & 71.94 & 73.43 \\
\hline & $t=0.047$ & $t=0.594$ & $t=-0.254$ & $t=1.110$ & $t=-0.088$ & $t=-0.719$ \\
\hline & $p=0.962$ & $p=0.553$ & $p=0.800$ & $p=0.268$ & $p=0.930$ & $p=0.473$ \\
\hline
\end{tabular}

\section{Discussion}

The predominance of women has been observed in other studies undertaken in Brazil. In a research carried out by VIGITEL, SAH affected $64.7 \%$ of elderly females ${ }^{(2)}$. Another study involving adults and elderly people with $\mathrm{SAH}$ in a rural community located in the Northeast of the state of Minas Gerais also showed a predominance of females $(51.6 \%)^{(14)}$.

In relation to age group, a similar situation was seen in a research involving the elderly in the rural area of Taquarituba-SP, which showed predominance of people between 60 and 70 years old $(57.7 \%)^{(15)}$. The monitoring of the elderly in this case is the responsibility of primary healthcare, with the aim of preventing comorbidities and avoiding the functional impairment of older people.

As for the marital status, these findings confirm those of a study involving the elderly living in the rural area of Taquarituba-SP, in which $53.8 \%$ stated to be married or to be in a de facto relationship ${ }^{(15)}$. In this context, the home visit is an important way of investigating the potential of the partner in supporting the SAH treatment, due to greater chances of identifying, in loco, the relationships established by the members of the family.

The level of education in this study is similar to the level found in a research involving adults and elderly with SAH living in a rural community located in the Northeast of the state of Minas Gerais, in which 39\% reported to have had one to four years of study ${ }^{(14)}$. The greatest difficulties for controlling blood pressure are related to low level of education(4-16).

In relation to the income, a different result was seen in a study carried out with the elderly living in the rural area of Taquarituba-SP, in which $36.5 \%$ stated to have an income of one to two minimum wages $^{(15)}$. Low income can compromise the treatment of the elderly with $\mathrm{SAH}_{\text {, }}$ in particular regarding diet and use of medications, when this is not covered by the public healthcare system. Moreover, the performance of medical examinations required for monitoring and control of $\mathrm{SAH}$ is also harder, due to the fact that these services are located in the city areas.

It can be stated that there is a need for healthcare professionals, together with the community, to adopt strategies for coping with these challenges resulting from lower socio-economic status, according to the availability of resources in each location and of healthcare services.

Concerning the living arrangements, a higher number $(52.8 \%)$ was seen in a research undertaken in Campinas-SP, which involved elderly with SAH who lived in the urban area(16). Partners may be involved in the treatment of elderly people with SAH to ensure better adherence to it, in case of a favorable relationship and, if this is not the case, to try to encourage partners to cooperate in order to improve the health conditions of both of them.

A study conducted in a healthcare unit, which focused on the elderly, verified that the members of a group found out to have $\mathrm{SAH}$ while seeking medical care and reporting signs and symptoms (headache, neck 
pain, dizziness, arm numbness), and the members of other group during a healthcare service's triage ${ }^{(17)}$.

An international study carried out in Australia and involving adults and the elderly living in rural areas showed that most elder females (77\%) checked their blood pressure, on average, once a year ${ }^{(18)}$. There are some factors that can interfere with the measurement of blood pressure, such as long distances between some farms and healthcare units and restricted access to transport. On the other hand, it is possible that elderly people do not consider it important to monitor blood pressure, taking into consideration that $\mathrm{SAH}$ is sometimes asymptomatic.

In a study carried out in the urban area of President Venceslau, in the state of Sao Paulo, more than $50 \%$ of the participants reported to have stopped drug therapy and the main reasons for this interruption were the following: the side effects, the fact that they did not feel anything and believed to be cured. Such findings indicate that the factor affecting adherence to SAH treatment was related to the elderly's understanding about the health-disease process ${ }^{(19)}$.

The literature shows that salt intake is still much higher among people with $\mathrm{SAH}$ than that recommended by the World Health Organization(3), which shows the need for incentives to reduce salt intake and processed products that have high salt content, highlighting the importance of changing this habit to control blood pressure.

Regarding QoL, a study involving the elderly living in rural areas showed that QoL was considered satisfactory and may be related to better adjustment to aging ${ }^{(20)}$. Health satisfaction can be related to the health care delivered to the elderly considering Family Health Strategy coverage.

The highest score in relation to the social relationships factor may be associated with greater affective connection with neighbors, friends and family, resulting from the stability of the elderly in rural areas ${ }^{(20)}$. The elderly's social relationships positively affect mental and psychological health(21), which facilitates the understanding about the disease and coping mechanisms, thus contributing to treatment adherence.

The environmental factor analyzes, among other factors, the financial resources, the availability and the quality of health and social care and transport ${ }^{(12)}$, which can be difficult in this area and negatively impact the QoL.

A study undertaken in a fishing community in Santa Catarina found that elderly people with chronic diseases are more concerned due to difficulties to get access to other healthcare resources and the worsening of health issues, which supposedly affects the QoL (21). In addition, it is shown that elderly people living in rural areas experience higher degree of poverty, with poorer homes, social isolation, restricted access to transport and distance from healthcare units ${ }^{(1)}$.

In relation to the intimacy aspect, it assesses the ability to maintain personal and intimate relationships ${ }^{(13)}$. $\mathrm{SAH}$ treatment requires health changes, such as diet and physical activities. Under this perspective, the present study's data indicate good personal relationships, showing that it is possible to work together with family members, in particular partners, given that most of them are married, towards being co-responsible in the healthcare of the elderly.

The social participation aspect assessed the participation in community activities ${ }^{(13)}$. A research found that elderly people with lower levels of education and income have more difficult access to leisure and fun, and this can affect their health conditions ${ }^{(15)}$. Rural areas offer fewer opportunities for social activities than city areas. The fact that most elderly people who participated in this study has a monthly income of one minimum wage can make it hard for them to participate in community activities and to have access to transport to other locations, which restricts social participation and compromises the QoL.

A study undertaken with elderly people living in a fishing community showed that QoL is related to energy and work, that is, to their physical ability(21). This fact may be associated with the chronic nature of $\mathrm{SAH}$, which progressively causes injuries to target-organs, thus compromising the QoL of the elderly.

Drug therapy aims at reducing cardiovascular events through blood pressure control and the consequent lower morbimortality related to the $\mathrm{SAH}^{(3)}$. The use of monotherapy is based on a pathophysiological mechanism of the patients and their personal features, number of morbidities, associated or not, and economic conditions $^{(3)}$. The use of drug therapy can be understood based on the particularities of each elderly, the action of the anti-hypertensive medication and the availability of the medication by the public healthcare service.

It is the multi-professional team's responsibility to assist with blood pressure control through SAH control without the use of medication and the adoption of lifestyle changes, besides making these elderly people understand the risks SAH can cause when left untreated. A research reviewing the multi-professional approach in relation to $\mathrm{SAH}$ control of the elderly highlighted that 
nurses establish a relationship of trust which includes socio-economic, physical and psychological aspects( ${ }^{(22)}$.

In relation to the medications used, direct vasodilators act on the muscles of the vascular wall, which relaxes with vasodilation and reduces the peripheral resistance and, as a consequence, can cause fluid retention and reflex tachycardia(3). Such side effects associated with drug dependence may affect the psychological aspect that assesses self-esteem, body image, positive and negative feelings ${ }^{(12)}$.

Concerning the IACE, it can have taste change as a side effect( ${ }^{(3)}$, which affects the functioning of senses.

As for the calcium channel blockers, they are effective in treating $\mathrm{SAH}$ and reducing the incidence of cerebrovascular accident (CVA), despite presenting some side effects, such as headache and dizziness ${ }^{(3)}$. The highest QoL score concerning the autonomy aspect can be related to the choice of medication for SAH treatment, which can promote a greater decision power of the elderly in relation to their treatment, so that the criteria for adopting a drug therapy used by a doctor should involve individual features and adjustment to the medication.

Due to vasodilation, this medication can cause reflex tachycardia and fluid retention ${ }^{(3)}$, which can affect the comparison of QoL among groups that use this medication. In addition to the side effects that cause discomfort, the use of other associated medications can affect the QoL. A research reviewing the elderly with $\mathrm{SAH}$ showed polypharmacy, often found among the elderly, as a restrictive factor in the anti-hypertensive treatment(22).

With regard to BRA II, they block the AT1 receptors and stop the effects of angiotensin II, being often used within patients with high cardiovascular risk and comorbidities, as it presents less intolerance and few side effects $^{(3)}$. The highest score concerning sensorial functioning may be associated with better adjustment to the medication on the part of the elderly, due to lesser side effects of the BRA II.

The results of the present research show the lack of knowledge on the part of the elderly in relation to their diseases, and the need to implement educational actions that approach SAH. It also highlights the importance of the educational role of the nurses concerning the understanding on the part of the elderly with SAH about the health-disease process. On the other hand, nurses should propose strategies to help the elderly remember to take their medication, how to put it always back in the same place or even seek the assistance of a family member. There is also the need to work on the recent memory of the elderly, through games and reading, in order to promote their independence in relation to healthcare. The need for actions like nursing consultations, home visits and health education activities with the purpose of providing information to the elderly about the prevention and complications of $\mathrm{SAH}$ and comorbidities can also be highlighted. Daily use of medication and their side effects can also be added, as well as the damage to target-organs that can result from $\mathrm{SAH}$ in the long term.

It is important to emphasize that nurses should establish a connection with the elderly and their families so that together they are able to develop strategies to improve adherence to SAH treatment, yet encouraging the elderly's independence. The advantages of treatment adherence, as well as monthly blood pressure measurement, the reduction of salt intake and the performance of physical activity are also noteworthy. These strategies can be encouraged individually or collectively, involving family members and valuing the rural areas. When checking the medications used by the elderly, nurses can inform them about the main side effects that affect the QoL, in a manner that reduces the impact in their daily lives. For such, greater emphasis should be given on the dynamism and autonomy of the elderly, aiming at improving treatment and consequently QoL. Furthermore, after the prescription of antihypertensive medication, it should be part of nursing care to clarify its functioning mechanism and follow up the elderly's adjustment to it.

\section{Conclusions}

Based on the above data, it can be said that there is a need for actions directed at the elderly with SAH living in rural areas, with the purpose of contributing to the improvement of issues related to the SAH and the encouragement of consultation and participation of these people in healthcare units, in order to promote a better QoL for this population. There is a need for healthcare professionals, mainly nurses, to have scientific knowledge that enables them to assist with the choice of treatment. They should be aware of the main benefits and drawbacks that medication can cause on the elderly, as well as of the issues related to adjustment and impact caused on the QoL.

\section{References}

1. Morais EP, Rodrigues RAP, Gerhardt TE. Os idosos mais velhos no meio rural: realidade de vida e saúde 
de uma população do interior gaúcho. Texto Contexto Enferm. 2008;17(2):374-83.

2. Ministério da Saúde (BR). DATASUS. Informações em Saúde. População residente - Brasil. [Internet]; 2009 [acesso 19 maio 2011]. Disponível em: http://tabnet. datasus.gov.br/cgi/tabcgi.exe?ibge/cnv/popuf.def

3. Sociedade Brasileira de Cardiologia/Sociedade Brasileira de Hipertensão/Sociedade Brasileira de Nefrologia. VI Diretrizes Brasileiras de Hipertensão. Arq Bras Cardiol. 2010;95(1 supl 1):1-51.

4. Mano GMP, Pierin AMG. Avaliação de pacientes hipertensos acompanhados pelo Programa Saúde da Família em um Centro de Saúde Escola. Acta Paul Enferm. 2005;18(3):269-75.

5. The Whoqol Group. The world health organization quality of life assessment: position paper from the world health organization. Soc Sci Med. 1995;41:1403-9.

6. Reis MG, Glashan RQ. Adultos hipertensos hospitalizados: Percepção de gravidade da doença e de qualidade de vida. Rev. Latino-Am. Enfermagem. 2001;9(3):51-7.

7. Brito DMS, Araujo TL, Galvano MTG, Moreira TMM, Lopes MVO. Qualidade de vida e percepção da doença entre portadores de hipertensão arterial. Cad Saúde Pública. 2008;24(4):933-40.

8. Youssef RM, Moubarak II, Kamel MI. Factors affecting the quality of life of hypertensive patients. Eastern Mediterranean Health J. 2005;11(1/2):109-8.

9. Aires M, Paskulin LMG, Morais EP. Capacidade functional de idosos mais velhos: estudo comparativo em três regiões do Rio Grande do Sul. Rev. Latino-Am. Enfermagem. 2010;18(1):11-7.

10. Bertolucci PH, Brucki SM, Campacci SR, Juliano Y. O mini-exame do estado mental em uma população geral: impacto da escolaridade. Arq Neuropsiquiatr. 1994;52(1):1-7.

11. Rodrigues RMC. Validação da versão em português europeu de questionário de avaliação functional multidimensional de idosos. Rev Panam Salud Publica. 2008;23(2):109-15.

12. Fleck MPA, Louzada SXM, Xavier M, Vieira G, Santos L, Pinzon V. Aplicação da versão em português do instrumento abreviado de avaliação da qualidade de vida "WHOQOL-bref". Rev Saúde Pública. 2000;34(2):178-83. 13. Fleck MPA, Chamovich E, Trentini CM. Development and validation of the Portuguese version of the WHOQOLOLD module / Desenvolvimento e validação da versão em Português do módulo WHOQOL-OLD. Rev Saúde Pública. 2006;40(5):785-91.
14. Pimenta AM, Kac Gilberto, Gazzinelli A, Oliveira RC, Melendez GV. Associação entre obesidade central, triglicerídeos e hipertensão arterial em uma área rural do Brasil. Arq Bras Cardiol. 2008;90(6):419-25.

15. Pinto JLG, Garcia ACO, Bocchi SCM, Carvalhaes MABL. Características de apoio social oferecido a idosos de área rural assistido pelo PSF. Ciênc Saúde Coletiva. 2006;11(3):753-64.

16. Zaitune MPA, Barros MBA, Cesar CLG, Carandina L, Goldbaum M. Hipertensão arterial em idosos: prevalência, fatores associados e práticas de controle no Município de Campinas, São Paulo, Brasil. Cad Saúde Pública. 2006;22(2):285-94.

17. Pinotti S, Mantovani MF, Giacomozzi LM. Perception on arterial hypertension and quality of life: Contribution to nursing care. Cogitare Enferm. 2008;13(4):526-34.

18. Janus ED, Bunker SJ, Kilkkinen A, Namara KMc, Philpot B, Tirimacco $R$, et al. Prevalence, detection and drug treatment of hypertension in a rural Australian population: the Great Green Triangle Risk Factor Study 2004-2006. Intern Med J. 2008;38:879-86.

19. Contiero AP, Pozati MPS, Challouts RI, Marcon SS. Idoso com hipertensão arterial: dificuldades de acompanhamento na Estratégia Saúde da Família. Rev Gaúcha Enferm. 2009;30(1):62-70.

20. Martins CR, Alburqueque FJB, Gouveia CNNA, Rodrigues CFF, Neves MTS. Avaliação da qualidade de vida subjetiva dos idosos: uma comparação entre os residentes em cidades rurais e urbanas. Estud Interdiscip Envelhec. 2007;11:135-54.

21. Meirelles BHS, Arruda C, Simon E, Vieira FMA, Cortezi MDV, Natividade MSL. Condições associadas com à qualidade de vida dos idosos com doenças crônicas. Cogitare Enferm. 2010;15(3):433-40.

22. Lyra DP Júnior, Amaral RT, Veiga EV, Cárnio EC, Nogueira MS, Pelá IR. A farmacoterapia no idoso: revisão sobre a abordagem multiprofissional no controle da hipertensão arterial sistêmica. Rev. Latino-Am. Enfermagem. 2006;14(3):435-41. 